\title{
Genetic Diversity of Begomoviruses Infecting Soybean, Bean and Associated Weeds in Northwestern Argentina
}

\author{
Patricia E. Rodríguez-Pardina1 ${ }^{1}$, F. Murilo Zerbini² \& Daniel A. Ducasse ${ }^{1}$ \\ ${ }^{1}$ INTA - Instituto de Fitopatologia y Fisiologia Vegetal, Camino 60 Cuadras Km 5 1⁄2 (5119) Córdoba, Argentina; \\ ${ }^{2}$ Departamento de Fitopatologia/BIOAGRO, Universidade Federal de Viçosa, CEP 36570-000, Viçosa, MG, Brazil, \\ e-mail: zerbini@ufv.br
}

(Accepted for publication 04/08/06)

Author for correspondence: F. Murilo Zerbini

Rodríguez-Pardina, P.E., Zerbini, F.M. \& Ducasse, D.A. Genetic diversity of begomoviruses infecting soybean, bean and associated weeds in Northwestern Argentina. Fitopatologia Brasileira 31:342-348. 2006.

\begin{abstract}
The subtropical Northwestern region of Argentina (provinces of Tucumán, Salta, Jujuy, Santiago del Estero and Catamarca) suffers from a high incidence of the whitefly Bemisia tabaci, and the detection of begomoviruses is also common. The Northwest is the main bean-growing region of the country, and approximately $10 \%$ of Argentina's soybean crop is grown in this area. We have used a PCR-based assay to establish the identity and genetic diversity of begomoviruses associated with bean and soybean crops in Northwestern Argentina. Universal begomovirus primers were used to direct the amplification of a fragment encompassing the 5' portion of the capsid protein gene. Amplified fragments were cloned, sequenced and subjected to phylogenetic analysis to determine the sequence identity to known begomoviruses. The data indicated the presence of four distinct begomoviruses, all related to other New World begomoviruses. The prevalent virus, which was present in $94 \%$ of bean and soybean samples and also in two weed species, is closely related to Sida mottle virus (SiMoV). A virus with high sequence identity with Bean golden mosaic virus (BGMV) was found in beans. The two remaining viruses displayed less than $89 \%$ identity with other known begomoviruses, indicating that they may constitute novel species. One of these putative novel viruses was detected in bean, soybean and tomato samples.
\end{abstract}

Additional keywords: Sida mottle virus, Bean golden mosaic virus, geminivirus.

\section{RESUMO}

Diversidade genética de begomovírus associados às culturas da soja e feijoeiro na região Noroeste da Argentina.

A região Noroeste da Argentina (províncias de Tucumán, Salta, Jujuy, Santiago del Estero e Catamarca), de clima subtropical, apresenta uma alta incidência da mosca-branca Bemisia tabaci e a detecção de begomovírus também é freqüente. O Noroeste é a principal região produtora de feijão do país e produz aproximadamente $10 \%$ da soja da Argentina. A identidade e diversidade genética de begomovírus associados à soja e ao feijoeiro no Noroeste da Argentina foram estudadas com base na amplificação de fragmentos do genoma viral via PCR, utilizando oligonucleotídeos universais para o gênero Begomovirus que amplificam um fragmento correspondente à região 5 ' do gene da proteína capsidial. Os fragmentos amplificados foram clonados e seqüenciados, e as seqüências foram submetidas à análise filogenética. Os resultados indicam a presença de quatro espécies de begomovírus, todas relacionadas às espécies do Novo Mundo. O vírus prevalente, detectado em $94 \%$ das amostras de feijoeiro e soja e em duas amostras de plantas daninhas, apresentou alta identidade de sequência e relacionamento filogenético com o Sida mottle virus (SiMoV). Um vírus com alta identidade de seqüência com o Bean golden mosaic virus (BGMV) foi detectado em feijoeiro. As duas outras espécies apresentaram menos de $89 \%$ de identidade com os demais begomovírus, sugerindo-se tratar de novas espécies. Uma dessas possíveis novas espécies foi detectada em plantas de feijoeiro, soja e tomateiro.

Palavras-chave adicionais: Sida mottle virus, Bean golden mosaic virus, geminivírus.

\section{INTRODUCTION}

Geminiviruses represent one of the major plant pathogens in tropical, subtropical and, to a more limited extent, temperate regions (Morales \& Anderson, 2001). Geminiviruses are characterized by their twinned icosahedral particles and circular single-stranded DNA genomes. The family Geminiviridae is divided into fourgenera(Mastrevirus, Curtovirus, Topocuvirus and Begomovirus), based on genome structure and phylogeny, type of insect vector and host range (Stanley et al., 2005). Begomoviruses are transmitted by whiteflies (Bemisia tabaci) to dicotyledonous plants. Most of the species in this genus have bipartite genomes consisting of two ssDNA molecules, referred to as DNA-A and DNA-B. Genes in DNA-A encode proteins responsible for viral replication (Rep and REn), regulation of gene expression (TrAP) and particle encapsidation (CP). Genes in DNA-B encode for two proteins (MP and NSP) 
involved in cell-to-cell movement within the plant, host range and symptom modulation. A region of approximately 200 nucleotides common to both genomic components contains cis-acting signals required for DNA replication and transcription (reviewed by Hanley-Bowdoin et al., 1999).

The subtropical Northwestern (NW) region of Argentina (provinces of Tucumán, Salta, Jujuy, Santiago del Estero and Catamarca) suffers from a high incidence of the whitefly Bemisia tabaci, and the detection of begomoviruses is also common (Vizcarret, 1999). This region is the main bean-growing area of the country, and approximately $10 \%$ of Argentina's soybean crop is grown in this area. Two begomoviruses have already been reported in bean crops in Argentina, Bean golden mosaic virus (BGMV) and Bean dwarf mosaic virus (BDMV) (Morales et al., 1990; Vizgarra, 1995; Zumelzu \& Docampo, 1984) but to our knowledge no molecular studies have been carried out to characterize these viruses. The occurrence of a begomovirus in soybean crops in NW Argentina was first reported in 1997 (Sakai et al., 1997). Molecular characterization showed that a virus related to Tomato golden mosaic virus (TGMV) was involved in the disease (Rodríguez-Pardina et al., 1998), but further evidence showed that more than one virus could be involved.

The objective of this study was to establish the identity and genetic diversity of begomoviruses associated with bean and soybean crops in Northwestern Argentina.

\section{MATERIALS AND METHODS}

Collection of plant samples. Leaf samples of soybean and bean plants showing typical begomovirus symptoms, such as severe yellow or golden mosaic, chlorotic mottling, blistering, leaf distortion and dwarfing (Figure 1), were collected in several fields located in the provinces of Catamarca, Tucumán, Salta and Jujuy, in Northwestern

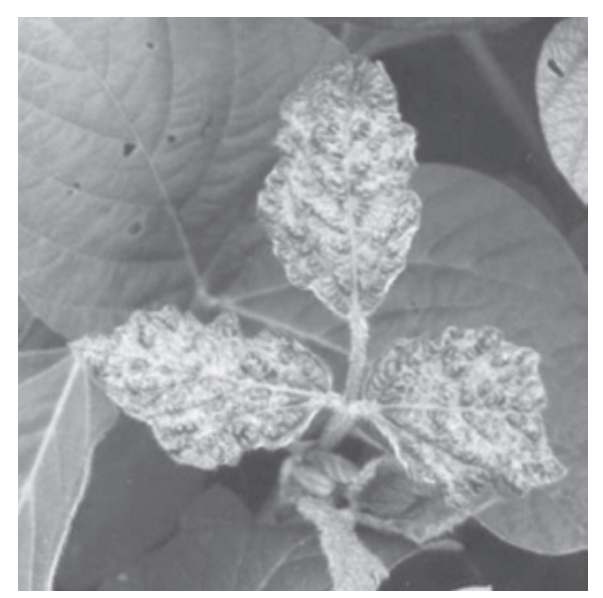

FIG. 1 - Symptoms of severe mosaic, blisters and leaf distortion in a soybean sample collected at Horcones, province of Salta, and PCR-positive for begomovirus infection.
Argentina. Additional soybean samples were collected in fields located in the Chaco province (Northeast), and north of the city of Córdoba, where soybean plants showing typical begomovirus symptoms were first observed during the 2003 growing season. A small number of tomato and weed samples showing golden mosaic symptoms were also collected. Weeds were often found bordering the crops or as undergrowth within them. All samples were freeze-dried and stored at $4^{\circ} \mathrm{C}$ until used for DNA extraction.

Confirmation of begomovirus infection. The presence of begomoviruses was initially confirmed by PCR, using primers PAL1v1978/PARc496 (Rojas et al., 1993) or MP16/MP82 (Umaharan et al., 1998), or by ELISA using the 3F7 antiserum (Agdia). For PCR, DNA was extracted using a CTAB protocol (Doyle \& Doyle, 1987). Reactions were carried out with puReTaq ReadyTo-Go PCR Beads (Amersham Biosciences), prepared in a $25 \mu \mathrm{l}$ volume containing $3 \mu \mathrm{l}$ of template DNA and a final primer concentration of $0.25 \mu \mathrm{M}$ (PAL1v1978/PARc496) or $0.75 \mu \mathrm{M}$ (MP16/MP82). Reactions were submitted to an initial denaturing step at $94^{\circ} \mathrm{C}$ for $3 \mathrm{~min}$, followed by 30 cycles of denaturing at $94^{\circ} \mathrm{C}$ for $1 \mathrm{~min}$, annealing at $50^{\circ} \mathrm{C}$ (PAL1v1978/PARc496) or $55^{\circ} \mathrm{C}$ (MP16/MP82) for $1 \mathrm{~min}$, and extension at $72^{\circ} \mathrm{C}$ for $2 \mathrm{~min}$, and a final extension at $72^{\circ} \mathrm{C}$ for $10 \mathrm{~min}$. Double-antibody sandwich ELISA was carried out using a commercial kit (Agdia) according to manufacturer's recommendations. Leaf samples were ground in four volumes of PBS $(1 \times)$ containing $0.5 \mathrm{ml} / 1$ Tween 20 and $20 \mathrm{~g} / 1 \mathrm{PVP}$ and incubated for $18 \mathrm{~h}$ at $4^{\circ} \mathrm{C}$ in ELISA Nunc 96-well Immunoplates. IgG and conjugate were each incubated for $4 \mathrm{~h}$ at $37^{\circ} \mathrm{C}$. After adding the substrate the reaction was quantified using a Dynatech MR 4000 ELISA plate spectrophotometer. Samples were considered positive when $\mathrm{A}_{450}$ values were higher than the mean plus three times the standard deviation of the values for healthy controls.

Cloning and sequencing procedures. DNA fragments from selected samples were amplified by PCR using primers MP16/MP82, which direct the amplification of a $\sim 450 \mathrm{bp}$ fragment encompassing the conserved nonanucleotide TAATATTAC at the origin of replication and the nucleotide sequence encoding eight conserved amino acids (CEGPCKVQ) at the 5' region of the capsid protein gene. PCR reactions were performed as described above. Amplification products were cloned using the TOPO TA Cloning kit (Invitrogen). The sequence of one to three clones from each sample was completely determined in both orientations using an ABI PRISM 377 automatic sequencer (Applied Biosystems).

Sequence analysis. Sequences were assembled and checked using DNAMan ver. 4.0 (Lynnon Biosoft). Database searches were carried out with Blastn (Altschul et al., 1990). Multiple sequence alignments of nucleotide sequences of the entire cloned fragment and the deduced 
amino acid sequences of the N-terminal region of the CP were performed with Clustal W ( www.ebi.ac.uk/clustalw). Phylogenetic trees were generated with MEGA 3.1 (Kumar et al., 2004) using the UPGMA method. Tree branches were bootstrapped with 2000 replications.

\section{RESULTS}

A total of 117 soybean and 124 bean samples with typical begomovirus symptoms were collected from several locations in Northwestern Argentina from 1993 to 2003. Forty-three (37\%) soybean and $32(26 \%)$ bean samples tested positive for the presence of begomoviruses, either by ELISA or PCR. In the province of Tucumán, 24 out of 62 soybean samples (38\%) were positive for begomovirus infection. Eight out of 16 soybean samples $(50 \%)$ collected in the province of Salta tested positive, while in Catamarca nine out of 35 soybean samples (26\%) were positive. Three soybean samples were collected in Córdoba and one of them $(33 \%)$ was positive for begomovirus infection. The single soybean sample collected in Chaco province was also positive. Eighty-four bean samples were collected in
Salta province, and 20 of them (24\%) tested positive for the presence of a begomovirus. In Santiago del Estero, 11 out of 36 bean samples $(30 \%)$ were infected. Four bean samples were collected in Jujuy province and one of them (25\%) tested positive. A total of 22 tomato samples were collected, all from the same field in Tucumán, and eight (36\%) were positive. Four weed samples (two of Leonurus sibiricus and one of Malvastrum coromandelianum collected in Salta, and one of Sida rhombifolia collected in Santiago del Estero) were positive for begomovirus infection.

DNA fragments amplified from 12 soybean and eight bean samples were selected for cloning, based primarily on the location where samples were collected and on the year of collection, in order to have samples from the largest possible number of locations and years of collection (Table 1). DNA fragments amplified from two tomato and three weed samples were also cloned (Table 1).

Fifty-six out of the 65 clones analyzed displayed greater than $90 \%$ sequence identity with Sida mottle virus (SiMoV, GenBank accession number NC_004637) for the first 69 amino acids of the capsid protein (Table 2). When the nucleotide sequence of the complete fragment

Table 1 - Plant species and geographic distribution of field collected samples selected for begomovirus molecular characterization. Only a fraction of the total number of samples tested for begomovirus infection is listed

\begin{tabular}{|c|c|c|c|c|c|}
\hline $\begin{array}{c}\text { Sample } \\
\text { code }\end{array}$ & Plant species & Field location & Province & Year & $\begin{array}{c}\text { Number of } \\
\text { clones sequenced }\end{array}$ \\
\hline L1 & Leonurus sibiricus & Metán & Salta & 2003 & 3 \\
\hline M2 & $\begin{array}{c}\text { Malvastrum } \\
\text { coromandelianum }\end{array}$ & El Tandíl & Salta & 2002 & 2 \\
\hline B3 & $\begin{array}{l}\text { Phaseolus vulgaris } \\
\text { (bean) }\end{array}$ & Isca Yacu & $\begin{array}{l}\text { Santiago del } \\
\text { Estero }\end{array}$ & 2002 & 3 \\
\hline B4 & bean & Isca Yacu & S. del Estero & 2002 & 3 \\
\hline B5 & bean & Pichanal & Salta & 2002 & 3 \\
\hline B6 & bean & La Junta & Salta & 2002 & 3 \\
\hline B7 & bean & Gral Ballivian & Salta & 2002 & 1 \\
\hline B8 & bean & Padre Lozano & Salta & 2003 & 2 \\
\hline B9 & bean & Padre Lozano & Salta & 2003 & 3 \\
\hline B10 & bean & Arrayanal & Jujuy & 2003 & 3 \\
\hline Sil1 & Sida rhombifolia & Pozo Hondo & S. del Estero & 2002 & 3 \\
\hline $\mathrm{S} 12$ & Glycine max (soybean) & Las Cañas & Salta & 1993 & 3 \\
\hline S13 & soybean & Horcones & Salta & 1995 & 3 \\
\hline S14 & soybean & Las Bajadas & Salta & 1998 & 1 \\
\hline S15 & soybean & Las Breñas & Chaco & 1999 & 3 \\
\hline S16 & soybean & R. de la Frontera & Salta & 2002 & 3 \\
\hline S17 & soybean & Cañetes & Tucumán & 2002 & 2 \\
\hline S18 & soybean & La Virginia & Tucumán & 2002 & 1 \\
\hline S19 & soybean & 7 de Abril & Tucumán & 2002 & 2 \\
\hline S20 & soybean & El Tandíl & Salta & 2002 & 3 \\
\hline $\mathrm{S} 21$ & soybean & Metán & Salta & 2003 & 3 \\
\hline S22 & soybean & El Abra & Catamarca & 2003 & 3 \\
\hline S23 & soybean & Totoral & Córdoba & 2003 & 3 \\
\hline $\mathrm{T} 24$ & $\begin{array}{c}\text { Lycopersicon } \\
\text { esculentum (tomato) }\end{array}$ & Vipos & Tucumán & 2000 & 3 \\
\hline $\mathrm{T} 25$ & (tomato) & Vipos & Tucumán & 2000 & 3 \\
\hline
\end{tabular}


Table 2 - Amino acid sequence identity of the N-terminal region of the capsid protein (before the slash) and nucleotide sequence identity of the entire amplified fragment (after the slash), between the different clones and the species with higher identity

\begin{tabular}{cccccc}
\hline \hline Clone & $\begin{array}{c}\text { Species with } \\
\text { higher identity }\end{array}$ & Clone & $\begin{array}{c}\text { Species with higher } \\
\text { identity }\end{array}$ & Clone & $\begin{array}{c}\text { Species with higher } \\
\text { identity }\end{array}$ \\
\hline L1-1 & SiMoV (91/91) & B9-3 & SiMoV (92/89) & S18-1 & SiMoV (92/90) \\
L1-2 & SiMoV (92/91) & B10-1 & SiMoV (92/89) & S19-1 & SiMoV (92/88) \\
L1-3 & SiMoV (92/91) & B10-2 & SiMoV (92/89) & S19-2 & SiMoV (92/91) \\
M2-1 & SiMoV (90/87) & B10-3 & SiMoV (91/89) & S20-1 & SiMoV (92/90) \\
M2-2 & SiMoV (89/87) & Si11-1 & SiMoV (90/85) & S20-2 & SiMoV (92/89) \\
B3-1 & SiMoV (92/89) & Si11-2 & SiMoV (91/85) & S20-3 & SiMoV (91/88) \\
B3-2 & SiMoV (92/89) & Si11-3 & SiMoV (92/85) & S21-1 & SiMoV (92/91) \\
B3-3 & TGMV (87/86) & S12-1 & SiMoV (91/88) & S21-2 & SiMoV (92/91) \\
B4-1 & SiMoV (92/89) & S12-2 & SiMoV (92/89) & S21-3 & SiMoV (92/91) \\
B4-2 & SiMoV (92/89) & S12-3 & SiMoV (91/89) & S22-1 & SiMoV (91/89) \\
B4-3 & SiMoV (92/89) & S13-1 & TGMV (89/87) & S22-2 & SiMoV (90/90) \\
B5-1 & SiMoV (92/89) & S13-2 & SiMoV (90/92) & S22-3 & SiMoV (91/89) \\
B5-2 & BGMV (97/92) & S13-3 & SiMoV (94/90) & S23-1 & SiMoV (92/89) \\
B5-3 & SiMoV (90/90) & S14-1 & SiMoV (92/89) & S23-2 & SiMoV (92/89) \\
B6-1 & SiMoV (92/89) & S15-1 & SiMoV (94/89) & S23-3 & SiMoV (91/90) \\
B6-2 & SiMoV (92/89) & S15-2 & SiMoV (94/90) & T24-1 & WGMV (84/78) \\
B6-3 & SiMoV (91/89) & S15-3 & SiMoV (94/90) & T24-2 & WGMV (83/76) \\
B7-1 & SiMoV (91/89) & S16-1 & SiMoV (94/91) & T24-3 & WGMV (75/74) \\
B8-1 & SiMoV (92/89) & S16-2 & SiMoV (94/90) & T25-1 & TGMV (87/83) \\
B8-2 & SiMoV (92/89) & S16-3 & SiMoV (92/91) & T25-2 & TGMV (86/84) \\
B9-1 & SiMoV (91/89) & S17-1 & SiMoV (92/89) & T25-3 & TGMV (87/84) \\
B9-2 & SiMoV (92/89) & S17-2 & SiMoV (91/89) & & \\
\hline
\end{tabular}

${ }^{a}$ Letters and numbers before the dash refer to the sample code in Table 1, and numbers after the dash refer to different clones obtained from each sample.

b SiMoV, Sida mottle virus; BGMV, Bean golden mosaic virus; TGMV, Tomato golden mosaic virus; WGMV, Wissadula golden mosaic virus.

was compared, including $200 \mathrm{bp}$ of the common region, maximum identities were $89 \%$ and $87 \%$ with two SiMoV isolates ( $\mathrm{NC} 004637$ and AJ557450), indicating that these clones could represent SiMoV isolates (Table 2). These 56 clones include clones obtained from all soybean, bean and weed samples analyzed, but none of the tomato samples.

Clone B5-2 displayed 97\% sequence identity with Bean golden mosaic virus (BGMV, NC_004042) for the first 69 amino acids of the capsid protein, and $92 \%$ identity at the nucleotide level for the complete fragment (Table 2). This result indicates that this clone may represent an isolate of BGMV, and that sample B5 had a mixed infection with SiMoV and BGMV, since clones B5-1 and B5-3 displayed $89 \%$ and $90 \%$ nucleotide sequence identity with SiMoV for the entire fragment, respectively (Table 2).

The remaining eight clones displayed less than $89 \%$ amino acid sequence identity to all begomovirus sequences currently deposited in the GenBank, indicating that these clones could represent novel species (Table 2). Two variants were found based on phylogenetic analysis (Figure 2). Variant A, showing the highest identity with Tomato golden mosaic virus (TGMV), was detected in soybean, bean and tomato samples (clones B3-3, S13-1, T25-1, T25-2 and T25-3), and variant B (close to Wissadula golden mosaic virus) was detected only in tomato (clones T24-1, T24-
2 and T24-3). Mixed infections were detected in soybean and bean plants. In soybean, SiMoV isolates were detected co-existing with variant $\mathrm{A}$ isolates (sample S13), whereas in bean, SiMoV was found with variant A (sample B3) and BGMV (sample B5).

Results of phylogenetic analysis demonstrated that most of the clones with higher sequence identity with SiMoV (eg B4-2, B8-1, L1-1, S12-2, S15-3, S23-1, and Si11-1) clustered with the original SiMoV isolate and with SiMoV-A1 (incorrectly named as SimMV in GenBank) (Figure 2). An exception was clone M2-1, which clustered with SimMV-A2, indicating that it could be an isolate of this species. The single clone identified as BGMV (B5-2) clustered with the original BGMV isolate. Clones classified as "variant A" (eg B3-3, S13-1 and T25-1) clustered with Tomato golden mosaic virus. Clones classified as "variant B" (eg, T24-1) did not form any evident cluster with known begomovirus species (Figure 2).

\section{DISCUSSION}

Begomovirus infection of beans has been reported in Argentina since the 1980's and attributed to BGMV (Morales \& Anderson, 2001), a virus which is widespread in the neighboring country of Brazil (Faria \& Maxwell, 1999). 


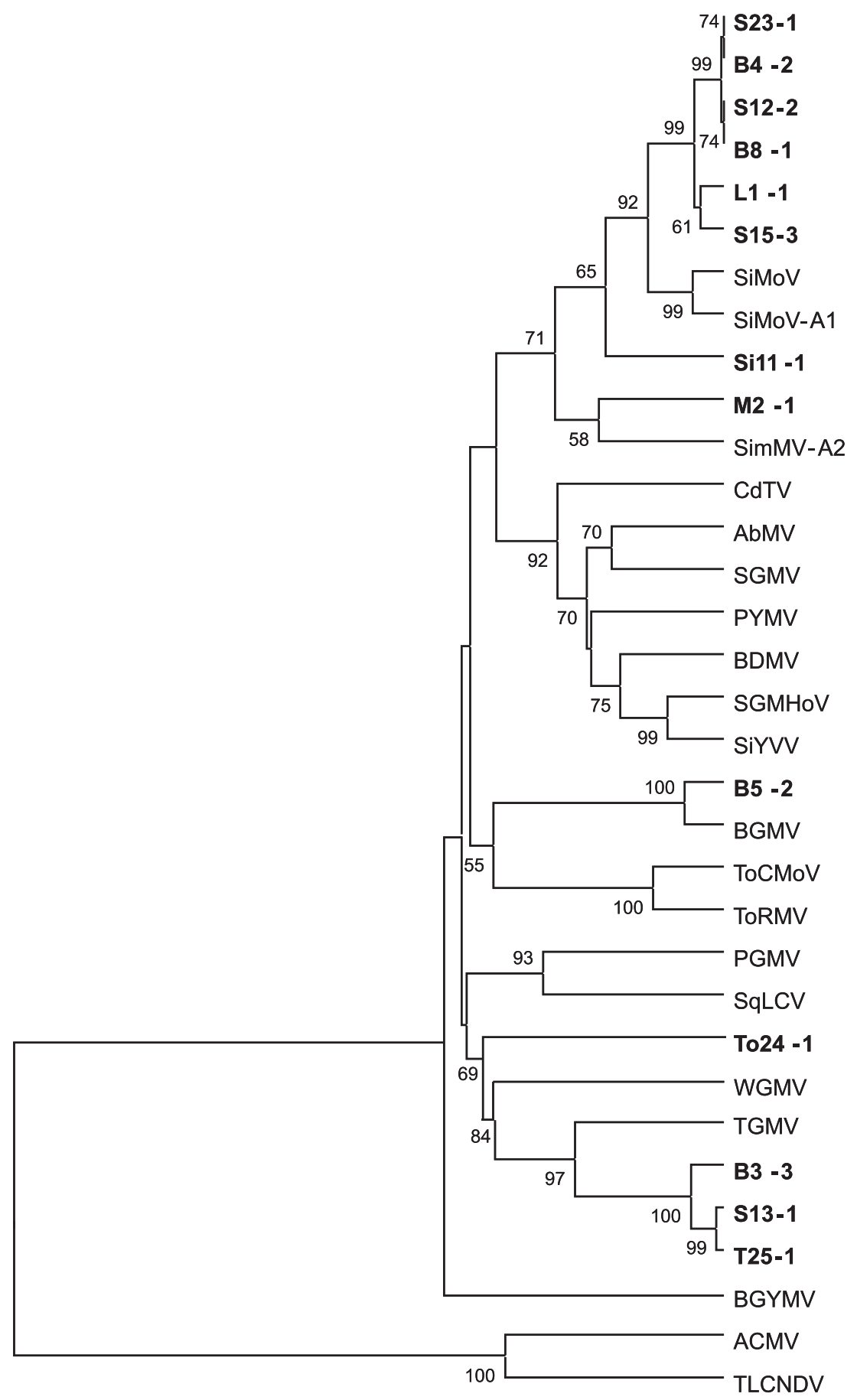

FIG. 2 - Phylogenetic tree based on the nucleotide sequence identity of the entire amplified fragment, generated using the UPGMA method. Branches were bootstrapped with 2000 replications (only values greater than 50\% are indicated). AbMV, Abutilon mosaic virus (GenBank accession number NC_001928); ACMV, African cassava mosaic virus (NC_001467); BDMV, Bean dwarf mosaic virus (NC_001931); BGMV, Bean golden mosaic virus (NC_004042); BGYMV, Bean golden yellow mosaic virus (NC_001439); CdTV, Chino del tomate virus, (NC_003830); PGMV, Pepper golden mosaic virus (NC_ 004101); PYMV, Potato yellow mosaic virus (NC 001934); SGMV, Sida golden mosaic virus (NC 002046); SGMHoV, Sida golden mosaic Honduras virus (NC_004659); SiMoV-A1, Sida mottle virus isolate A1 (AJ557450); SimMV-A2, Sida micrantha mosaic virus isolate A2 (NC_005330); SiMoV, Sida mottle virus (NC_004637); SiYVV, Sida yellow vein virus (NC_004661); SqLCV, Squash leaf curl virus (NC_001936); TGMV, Tomato golden mosaic virus (NC_001507); ToCMoV, Tomato chlorotic mottle virus (NC_003664); TLCNDDV, Tomato leaf curl New Delhi virus (NC_004611); ToRMV, Tomato rugose mosaic virus (NC_002555); WGMV, Wissadula golden mosaic virus (U69280). 
Although bean-infecting begomoviruses are disseminated throughout the Americas, soybean-infecting begomoviruses are much less common. In fact, the first reports of soybean infection by begomoviruses in Argentina and Brazil took place only recently (Mello et al., 2000; Mello et al., 2002; Rodríguez-Pardina et al., 1998), and these remain as the only countries in the Western hemisphere where soybeaninfecting begomoviruses have been reported.

Here, we attempted to characterize the begomoviruses infecting soybean and bean in Northwestern Argentina, the main bean-growing region of the country and an important soybean-growing area as well. Samples were collected in all provinces of NW Argentina, over a period of ten years. However, most of the samples $(90 \%)$ were collected in the years 2002 to 2003 . Overall, approximately $37 \%$ and $26 \%$ of soybean and bean samples, respectively, tested positive for the presence of a begomovirus. In soybean, 38, 50 and $26 \%$ of the samples collected in the provinces of Tucumán, Salta and Catamarca, respectively, tested positive for the presence of a begomovirus. In bean, 24, 25 and $30 \%$ of the samples collected in the provinces of Salta, Jujuy and Santiago del Estero were positive. Although it is not possible to correlate these data with the incidence of begomovirus infection in the field (since only samples with obvious viruslike symptoms were collected), these results indicate a high relative incidence of begomoviruses compared to the other viruses which infect soybean and bean.

Although the portion of the viral genome sequenced was small, it included 200 nucleotides (nt) at the 5 ' region of the $c p$ gene, which is highly variable and has been proposed as an informative region for predicting taxonomic relationships within the genus Begomovirus (Brown et al., 2001; Padidam et al., 1995). Definitive species assignment requires sequencing of the complete DNA-A, especially considering the high recombination rate of begomovirus genomes (Preiss \& Jeske, 2003). We cannot rule out the presence of recombinant viruses in the field, which would not be detected using our strategy. However, considering the high degree of identity among most isolates and previously characterized begomoviruses, tentative species assignments are possibly quite reliable.

A virus with high sequence identity and phylogenetic relationship with SiMoV was found in $100 \%$ of bean and soybean samples, and was also detected in Leonurus sibiricus and Malvastrum coromandelianum. SiMoV was first reported in Brazil infecting Sida rhombifolia (Fernandes et al., 1999), and three years later it was detected in soybean samples also from Brazil (Mello et al., 2002). This is the first report of this virus (or a closely related new virus) in Argentina, and appears to be its first report infecting $L$. sibiricus, M. coromandelianum and bean. Surprisingly, from the eight bean samples analyzed, only one had BGMV, and still this sample was co-infected with the SiMoV-like virus. In all other areas of the world where BGMV or Bean golden yellow mosaic virus (BGYMV) are present, they are by far the most prevalent viruses in this crop. Thus, NW
Argentina seems to be an exception to this rule. The reasons for this prevalence are unknown, but it could have important epidemiological consequences considering that this virus has also been detected in soybean in Brazil. If the conditions that allowed this virus to be prevalent in Argentina are somehow reproduced in Brazil, it is not unreasonable to suppose that SiMoV could eventually replace BGMV as the main beaninfecting begomovirus in that country.

The virus detected in soybean, bean and tomato samples, named "variant A", displayed a maximum sequence identity (87\%) with TGMV, and is probably the same isolate found in soybean crops in earlier studies (Rodríguez-Pardina et al., 1998) and tentatively identified as TGMV at that time based on partial sequence comparisons. It has a wide host range in terms of economically important crop species (soybean, bean and tomato), which makes it attractive in terms of its biological properties and host interactions.

"Variant B" was found at a very low incidence. It was detected in a single tomato sample. Further studies have to be carried out in order to establish its real incidence in tomato crops. However, its detection is an indicative of the diversity among the native begomovirus flora of Argentina. This isolate could be a source of additional variation that could drive begomovirus evolution by means of recombination and pseudorecombination.

\section{REFERENCES}

ALTSCHUL, S.F., GISH, W., MILLER, W., MYERS, E.W. \& LIPMAN, D.J. Basic local alignment search tool. Journal of Molecular Biology 215:403-410. 1990.

BROWN, J.K., IDRIS, A.M., TORRES-JEREZ, I., BANKS, G.K. \& WYATT, S.D. The core region of the coat protein gene is highly useful for establishing the provisional identification and classification of begomoviruses. Archives of Virology 146:15811598. 2001.

DOYLE, J.J. \& DOYLE, J.L. A rapid DNA isolation procedure for small amounts of fresh leaf tissue. Phytochemical Bulletin 19:1115. 1987.

FARIA, J.C. \& MAXWELL, D.P. Variability in geminivirus isolates associated with Phaseolus spp. in Brazil. Phytopathology 89:262-268. 1999.

FERNANDES, A.V., GALVÃO, R.M., MACHADO, J.J., ZERBINI, F.M. \& FONTES, E.P.B. Cloning and molecular characterization of A components of two new Sida rhombifoliainfecting geminiviruses. Virus Reviews and Research 4(Supl.): 148. 1999.

HANLEY-BOWDOIN, L., SETTLAGE, S.B., OROZCO, B.M., NAGAR, S. \& ROBERTSON, D. Geminiviruses: Models for plant DNA replication, transcription, and cell cycle regulation. Critical Reviews in Plant Sciences 18:71-106. 1999.

KUMAR, S., TAMURA, K. \& NEI, M. MEGA3: Integrated software for molecular evolutionary genetics analysis and sequence alignment. Briefings in Bioinformatics 5:150-163. 2004.

MELLO, R.N., ALMEIDA, A.M.R. \& ZERBINI, F.M. Detection 
and identification of geminiviruses infecting soybean and associated weeds in Brazil. Fitopatologia Brasileira 25(Supl.):444. 2000.

MELLO, R.N., COTRIM, M.A.A., LOPES, E.F., MOREIRA, A.G., CONTIN, F.S., FONTES, E.P.B., ALMEIDA, A.M.R. \& ZERBINI, F.M. Survey of begomoviruses associated with soybean and identification of Sida mottle virus (SiMoV) infecting this crop in Brazil. Virus Reviews and Research 7(Supl.):157. 2002.

MORALES, F., NIESSEN, A., RAMIREZ, B. \& CASTAÑO, M. Isolation and partial characterization of a geminivirus causing bean dwarf mosaic. Phytopathology 80:96-101. 1990.

MORALES, F.J. \& ANDERSON, P.K. The emergence and dissemination of whitefly-transmitted geminiviruses in Latin America. Archives of Virology 146:415-441. 2001.

PADIDAM, M., BEACHY, R.N. \& FAUQUET, C.M. Classification and identification of geminiviruses using sequence comparisons. Journal of General Virology 76:249-263. 1995.

PREISS, W. \& JESKE, H. Multitasking in replication is common among geminiviruses. Journal of Virology 77:2972-2980. 2003.

RODRÍGUEZ-PARDINA, P.E., PLOPER, D., LAGUNA, I.G., TRUOL, G.A., HANADA, K., RIVAS-PLASTERO, G.G., RAMIREZ, P. \& HERRERA, P.S. Presencia de un geminivirus en cultivos de soja del Noroeste Argentino. Avance Agroindustrial 19:38-41. 1998.

ROJAS, M.R., GILBERTSON, R.L., RUSSELL, D.R. \& MAXWELL, D.P. Use of degenerate primers in the polymerase chain reaction to detect whitefly-transmitted geminiviruses. Plant Disease 77:340-347. 1993.
SAKAI, J., RODRIGUEZ-PARDINA, P.E., ONUKI, M., USUGI, T., SHOHARA, K. \& HANADA, K. Nucleotide sequence of a geminivirus isolate detected from soybean showing yellow and rogues symptoms in Argentina. Annals of the Phytopathological Society of Japan 63:270. 1997.

STANLEY, J., BISARO, D.M., BRIDDON, R.W., BROWN, J.K., FAUQUET, C.M., HARRISON, B.D., RYBICKI, E.P. \& STENGER, D.C. Family Geminiviridae. pp.301-326 In: Fauquet, C.M., Mayo, M.A., Maniloff, J., Desselberger, U. \& Ball, L.A.(Eds.) Virus Taxonomy. Eighth Report of the International Committee on Taxonomy of Viruses. San Diego Elsevier Academic Press. 2005.

UMAHARAN, P., PADIDAM, M., PHELPS, R.H., BEACHY, R.N. \& FAUQUET, C.M. Distribution and diversity of geminiviruses in Trinidad and Tobago. Virology 88:1262-1268. 1998.

VIZCARRET, M.M. La situación actual de las moscas blancas en la Argentina: Perspectivas de Manejo. pp. 59-63 In: VIII Encontro Latino-americano e do Caribe sobre Moscas Brancas e Geminivirus Recife, PE, Brazil. 1999. (Abstract)

VIZGARRA, O. Epidemiologia y control integrado de las virosis del poroto transmitidas por mosca blanca en el Noroeste de Argentina. Avance Agroindustrial 16:33-34. 1995.

ZUMELZU, G. \& DOCAMPO, D.M. Partículas icosaédricas asociadas al achaparramiento del poroto (Phaseolous vulgaris) Tipo Alubia y el moteado presente en otos cultivares. pp. 105 In: VII Reunión Nacional y I Internacional de la Sociedad de Olericultura Buenos Aires, Argentina. 1984. (Resumo) 